\title{
International Law in Asia: A Bibliographic Survey
}

\author{
Jeong Woo Kim \\ Research Fellow, DILA \\ Adjunct Lecturer, Law Department, Handong Global University
}

\section{EDITORIAL INTRODUCTION}

This bibliography provides information on books, articles, and other materials dealing with public and private international law in Asia, broadly defined. Only English language publications are listed. In the preparation of this bibliography, good use has been made of the list of acquisitions of the Peace Palace Library in The Hague, The Netherlands, as well as book reviews in journals of international law, Asian studies, and international affairs. Most, if not all, of the materials can be listed under two or more categories, but in order to save space, each item has been placed under one category.

The bibliography is limited to new materials published in 2011, or in some cases, previously published materials that have new editions in 2011. In addition, some materials that are listed as published in 2010, but were made available in 2011, are included here as well. Such entries are marked with an asterisk $\left({ }^{*}\right)$. The headings used in this year's bibliography are as follows:

1. General

2. States or group of states

3. Territory and the law of the sea

4. Watercourses

5. Air and Space

6. Environment

7. NGOs

8. Jus ad bellum, jus in bello, and security

9. International criminal law

10. International dispute settlement 
11. Diplomatic relations

12. Human rights and state practice

13. Colonialism, decolonization, and self determination

14. International economic and financial law

15. Development

16. Information and communication

17. International/regional organizations

18. Private International law

19. Nuclear

20. Cultural property

\section{GENERAL}

Black, E. Ann \& Bell, Gary F., Law And Legal Institutions Of Asia: Traditions, Adaptations And Innovations (Cambridge University Press 2011).

Chimni, B.S., Asian Civilizations and International Law: Some reflections, 1 Asian Journal Of International Law 39-42 (2011).

Onuma, Yasuaki, The Asian Society of International Law: Its birth and significance, 1 Asian Journal Of International LaW 71-82 (2011).

Owada, Hisashi, Asia and International Law: The inaugural address of the first president of the Asian Society of International Law, Singapore, 7 April 2007, 1 Asian Journal Of International LaW 3-11 (2011).

Pan, Junwu, Chinese Philosophy and International Law, 1 Asian JournaL OF INTERNATIONAL LAW 233-248 (2011).

Shelton, Dinah, International Law And Domestic Legal Systems: Incorporation, Transformation, And Persuasion (Oxford University Press 2011).

Steiger, Heinhard \& Marauhn, Thilo, Universality And Continuity In International LaW (Eleven International Publishing 2011).

Tomuschat, Christian, Asia and International Law: Common ground and regional diversity, 1 Asian Journal Of International Law 217231 (2011). 


\section{STATES OR GROUP OF STATES}

${ }^{*}$ Ando, Nisuke, The Khoka-Ryo Case and International Law: A critique of the Japanese Supreme Court decision, 53 Japanese Yearbook Of INTERNATIONAL LAW 1-18 (2010).

Carty, Tony, Why are Hong Kong Judges keeping a Distance from International Law, and with what Consequences?: Reflections on the CFA decision In "DRC V Fg Hemisphere", 41 Hong Kong Law Journal 401-410 (2011).

Cummings, Sally N. \& Hinnebusch, Raymond, Sovereignty After Empire: Comparing The Middle East And Central Asia (Edinburgh University Press 2011).

Dogauchi, Masato, New Japanese Rules on International Jurisdiction: General observation, 54 Japanese Yearbook Of International LAW 260-277 (2011).

Gulati, Rishi, The 26/11 Mumbai Terrorist Attacks: Assessing Pakistan's responsibility in international law, 51 Indian Journal Of InTERNATIONAL LAW 321-363 (2011).

*Jia, Bing Bing, A Synthesis of the Notion of Sovereignty and the Ideal of the Rule of Law: Reflections on the contemporary Chinese approach to international law, 53 German Yearbook Of International LAW 11-61 (2010).

Liu, Zhiyun, Interdisciplinary Research on International Relations Theory and International Law in China over the Past 10 Years, 6 Frontiers Of LaW In China 496-523 (2011).

Mason, Whit, The Rule Of Law In Afghanistan: Missing In Inaction (Cambridge University Press 2011).

Mushkat, Roda, State Reputation and Compliance with International Law: Looking through a Chinese lens, 10 CHINESE Journal Of InTERnATIONAL LAW 703-737 (2011).

Mushkat, Roda, The Dynamics of International Legal Regime Formation: The Sino-British joint declaration on the question of Hong Kong revisited, 22 European Journal Of International Law 1119-1144 (2011). 
Ruskola, Teemu, China's Approach to International Law: A historical perspective, 94 American SOCiety International LaW 267 (2011).

Svarverud, Rune, Re-constructing East Asia: International law as intercultural process in late Qing China, 12 InTER-Asia Cultural STUdIES 306-318 (2011).

Swigert, Stephanie, Burmese Government in Exile: Outcast but not irrelevant, 39 Legal Journal On Burma 31-38 (2011).

Tan, Kevin Yl., International Law, History \& Policy: Singapore In The Early Years. Monogra ph No. 1 (Centre for International Law National University of Singapore 2011).

Tan, Kevin Yl., Singapore And International Law: The Early Years - Essays In Memory Of S. Tiwari (ISEAS Publishing 2011).

* Yakushiji, Kimio, Legislation of the Act on Civil Jurisdiction over Foreign States, Acceptance of the U.N. Convention on Jurisdictional Immunity of States and Their Property, and Their Possible Effects upon the Jurisprudence of Japanese Domestic Courts on State Immunity, 53 Japanese Yearbook Of International Law 202-242 (2010).

Yang, Zewei, Western International Law and China's Confucianism in the 19th Century: Collision and integration, 13 Journal Of The History Of INTERNATIONAL LAW 285-306 (2011).

Zeng, Lingliang, The Chinese Practice of International Rule of Law: Great progress in the past thirty years and growing challenges ahead, 14 WuHAN University International LaW Review 1-24 (2011).

Zou, Keyuan, International Law In East Asia (Ashgate 2011).

\section{TERRITORY AND THE LAW OF THE SEA}

Ad hoc Editorial Chamber, Whaling Dispute in the South Pacific: A Japanese perspective, 4 Journal Of East Asia \& International Law 449-456 (2011).

Diba, Bahman Aghai, Iran And The International Law Of The Seas And Rivers (CreateSpace Independent Publishing Platform 2011).

Carty, Anthony \& Lone, Fozia Nazir, Some New Haven International Law Reflections on China, India and their Various Territorial Disputes, 19 Asia Pacific Law Review 93-112 (2011). 
Chi, Manjiao, Unhelpfulness of Treaty Law in Solving the Sino-Japan Sovereign Dispute over the Diaoyu Islands, 6 EAst Asia Law Review 163-190 (2011).

Davis, Ruth, Whaling Dispute in the South Pacific: An Australian Perspective, 4 Journal Of East Asia \& International Law 419-448 (2011).

Franckx, Erik, American and Chinese Views on Navigational Rights of Warships, 10 (1) Chinese Journal Of International LaW 187206 (2011).

Konstantinidis, Ioannis, Dispute Settlement in the Law of the Sea, the Extended Continental Shelf in the Bay of Bengal and the CLCS: Some preliminary observations on the basis of the case Bangladesh/ Myanmar before the International Tribunal for the Law of the Sea, 1 (2) Aegean Review Of The Law Of The Sea And Maritime Law 267-285 (2011).

Park, Maya, Japanese Scientific Whaling in Antarctica: Is Australia attempting the impossible?, 9 New Zealand Journal Of Public \& INTERNATIONAL LAW 193-221 (2011).

Pedrozo, Raul (Pete), Responding to Ms. Zhang's Talking Points on the EEZ, 10 (1) Chinese Journal Of International Law 207-223 (2011).

Rieser, Alison, The Papahanaumokuakea Precedent: Ecosystem-scale marine protected areas in the EEZ, 13 Asian-PACIFIC LAW \& Policy JOURNAL 210-251 (2011).

Xue, Guifang, Deep Danger: Intensified competition in the South China Sea and implications for China, 17 OCEAN \& CoAstal LAw Journal 307-331 (2011).

Yee, Andy, Maritime Territorial Disputes in East Asia: A comparative analysis of the South China Sea and the East China Sea, 40 (2) Journal Of Current Chinese Affairs 165-193 (2011).

Hamamoto, Shotaro, Collision between Japan Coast Guard Patrol Vessels and a Trawler in the Waters off the Senkaku Islands Chinese Fishing, 54 Japanese Yearbook Of International Law 434-442 (2011).

Lee, Seokwoo \& Lee, Hee Eun, Dokdo: Historical Appraisal And International Justice (Martinus Nijhoff Publishers 2011). 
Schofield, Clive \& Storey, Ian, The South China Sea Dispute: Increasing Stakes And Rising Tensions (Jamestown Foundation 2011).

Storey, Ian, Southeast Asia And The Rise Of China: The Search For SECURITy (Routledge 2011).

Thuy, Tran Truong, The South China Sea: Towards A Region Of Peace, Security And Cooperation (Thẽ Giói Publishers [Diplomatic Academy of Vietnam] 2011).

Wagener, Marti, Lessons from Preah Vihear: Thailand, Cambodia, and the nature of low-intensity border conflicts, 30 Journal Of CUrrent Southeast Asian Affairs 27-59 (2011).

Gau, Michael Sheng-ti, Problems and Practices in Maritime Delimitation in East Asia: With special reference to Taiwan, 4 Journal Of EAst Asia \& International LaW 377-404 (2011).

\section{WATERCOURSES}

Bichsel, Christine, Liquid Challenges: Contested water in Central Asia, 12 (1) Sustainable Development Law \& Policy 24-30, 58-60 (2011).

Suhardiman, Diana et al., Scalar Disconnect: The logic of transboundary water governance in the Mekong, 25(6) Society \& Natural ReSOURCES 572-586 (2011).

Vinogradov, Sergei, Managing transboundary water resources in the Aral Sea Basin: In search of a solution, 1 International Journal Of Global Environmental Issues 345-362 (2011).

\section{AIR AND SPACE}

Gong, Xiangqian, New Development of International Law on Civil Aviation Security: The Beijing Convention and Beijing Protocol of 2010, 4 Journal Of East Asia \& International Law 232-234 (2011).

Ling, Yan, Prevention of Outer Space Weaponization under International Law: A Chinese lawyer's perspective, 4 Journal Of EAst Asia \& INTERNATIONAL LAW 271-290 (2011).

Zhao, Yun, Way Forward for Promoting Awareness of Space Law in Asia: A proposal for institutional capacity building, 4 Journal Of EAst Asia \& International LAW 335-350 (2011). 


\section{ENVIRONMENT}

Wibisana, Andri G., The Development of the Precautionary Principle in International and Indonesian Environmental Law, 14 Asia PACIFIC Journal Of Environmental Law 169-202 (2011).

Barresi, Paul A., U.S.-China Relations and the Fate of the UN Framework Convention on Climate Change: Traditional conservatism as an ideological and cultural constraint on U.S. participation in a successor to the Kyoto Protocol on Chinese Terms, 10 (3) Chinese Journal Of INTERNATIONAL LAW 609-649 (2011).

Cao, Mingde \& Wang, Fengyuan, Environmental Public Interest Litigation in China, 19 Asia Pacific Law Review 217-236 (2011).

Eisen, Joel B., China's Greentech Programs and the USTR Investigation, 11

(2) Sustainable Development Law \& Policy 3-8 (2011).

Gong, Xiangqian, Undertaking the Common but Differentiated Responsibilities - China's Decision to Accept the Two Amendments to the Montreal Protocol on Substances That Deplete the Ozone Layer, 4 Journal Of East Asia \& International Law 515-518 (2011).

Jiang, Xiaoyi \& Hao, Fahui, Legal Issues for Implementing the Clean Development Mechanism in China, 4 Journal Of East Asia \& INTERNATIONAL LAW 7-40 (2011).

Johnstone, Naomi, Commercialism and Conservationism: Law in the forests of Indonesia from colonisation to climate change, 14 Asia Pacific Journal Of Environmental Law 21-42 (2011).

Kapur, Kavita, Climate Change, Intellectual Property, and the Scope of Human Rights Obligations, 11 (2) Sustainable Development LaW \& Policy 58-63 (2011).

Litta, Henriette, Regimes In Southeast Asia: An Analysis Of EnviRONMENTAL COOPER ATION (VS Verlag für Sozialwissenschaften 2011). 
Liu, Nengye \& Maes, Frank, Prevention of Vessel-Source Marine Pollution: A note on the challenges and prospects for Chinese practice under international law, 42 Ocean Development And International LAW 356-367 (2011).

Mushkat, Roda, The Development of Environmental Governance Regimes: A Chinese-inspired reconstruction, 2 WASHINGTON \& LeE JournaL Energy, Climate \& Environment 1-49 (2011).

Stevenson, Hayley, India and International Norms of Climate Governance: A constructivist analysis of normative congruence building, $37 \mathrm{RE}-$ view Of International Studies 997-1019 (2011).

$\mathrm{Su}$, Yiyuan, International Legal Concerns on Climate Change Regime: Taiwan's perspective, 4 Journal Of East Asia \& International LAW 63-80 (2011).

Trepagnier, P. Cal, Singapore Workaround: Providing a greenprint for a UNFCCC party reclassification, 11 (2) Sustainable Development LaW \& Policy 66-68 (2011).

Wang, Hui, Civil liability For Marine Oil Pollution Damage: A Comparative And Economic Study Of The International, US And The Chinese Compensation Regime (Kluwer Law International 2011).

Yoshida, Osamu, Procedural Aspects of the International Legal Regime for Climate Change: Early operation of the Kyoto Protocol's compliance system, 4 Journal Of East Asia \& International Law 41-62 (2011).

Zhou, Xin \& Mori, Hideyuki, National Institutional Response to Climate Change and Stakeholder Participation: A comparative study for Asia, 11 International Environmental Agreements: Politics, Law And ECONOMics 297-319 (2011).

\section{NGOS}

Li, Yuwen, NGOs In China And Europe: Comparisons And Contrasts (Ashgate 2011). 


\section{JUS AD BELLUM, JUS IN BELLO, AND SECURITY}

Howland, Douglas, Sovereignty and the Laws of War: International consequences of Japan's 1905 victory over Russia, 29 LAW And History Review 53-97 (2011).

Johnson, Robert, Japan Closes the Nuclear Umbrella: An examination of nonviolent pacifism and Japan's vision for a nuclear weapon-free world, 13 Asian-Pacific LaW \& Policy Journal 81-116 (2011).

Kimijima, Akihiko, Global Constitutionalism and Japan's Constitutional Pacifism, 23 (3) Ritsumeikan Kokusai Kenkyu 465 (2011).

Lay, Vicheka, Convention on Cluster Munitions, 4 Journal Of East Asia \& InTERnATIONAL LAW 229-31 (2011).

Pham, Quang Minh, The East Asia Security Environment in the Beginning of the Twenty-first Century and the Adjustments in Vietnamese Foreign Policy, 18 (1) Asia-Pacific Review 98-108 (2011).

Reeves, Caroline, Sovereignty and the Chinese Red Cross Society: The differentiated practice of international law in Shandong, 1914-1916, 13 Journal Of The History Of International Law 155-177 (2011).

Tladi, Dire \& Taylor, Gillian, On the Al Qaida/Taliban Sanctions Regime: Due process and sunsetting, 10 (4) Chinese Journal Of InternaTIONAL LAW 771-789 (2011).

Bellal, Annyssa \& Giacca, Gilles \& Casey-Maslen, Stuart, International Law and Armed Non-State Actors in Afghanistan, 93 InTERnational Review Of The Red Cross 47-79 (2011).

Hindawi, Coralie Pison, The Controversial Impact of WMD Coercive Arms Control on International Peace and Security: Lessons from the Iraqi and Iranian cases, 16 Journal Of Conflict And Security LaW 417-442 (2011).

Kim, Suk Kyoon, Maritime Security Initiatives in East Asia: Assessment and the way forward, 42 Ocean Development And International LAW 227-244 (2011).

Orr, Andrew C., Unmanned, Unprecedented, and Unresolved: The status of American drone strikes in Pakistan under international law, 44 Cornell International LaW Journal 729-752 (2011). 
Suhrke, Astri, When More Is Less: The International Project In Afghanistan (Hurst 2011).

Terry, Fiona, The International Committee of the Red Cross in Afghanistan: Reasserting the neutrality of humanitarian action, 93 INTERNATIONAL Review Of The Red Cross 173-188 (2011).

Terry, Patric C.R., International Law Strikes Back "or" Suez 1956: A forerunner of the Iraq Fiasco in 2003, 4 Journal Of African And INTERNATIONAL LAW 327-370 (2011).

Woo, Jongseok, Security Challenges And Military Politics In East Asia: From State-Building To Post-Democratization (Continuum 2011).

Dutton, Pia, Action in Burma: The international rule of politics, 39 LEGAL Journal On Burma 46-72 (2011).

\section{INTERNATIONAL CRIMINAL LAW}

Aljazy, Ibrahim, The Implementation of International Criminal Law in Arab States: The Jordanian Experience, in Criminal Law Reform And Transitional Justice: Human Rights Perspectives For Sudan 183-195 (Lutz Oette ed., Ashgate 2011).

Ambos, Kai, Judicial Creativity at the Special Tribunal for Lebanon: Is there a crime of terrorism under international law?, 24 LEIDEN JOURNAL Of INTERNATIONAL LAW 655-675 (2011).

Aronofsky, David \& Qin, Jie, U.S. International Narcotics Extradition Cases: Legal trends and developments with implications for U.S.China drug enforcement activities, 19 Journal Of INTERNATIONAL LAw And Practice 279-297 (2011).

Banerjee, Rishav, Rome Statute and India - An analysis of India's attitude towards the International Criminal Court, 4 Journal Of EAST Asia And International LAW 457-476 (2011).

Bari, M. Ehteshamul, Dispensation of Justice by the Extraordinary Chambers in the Courts of Cambodia: A critical appraisal, 4 Journal OF East Asia And International Law 193-217 (2011). 
Cerone, John, The Politics of International Justice: U.S. Policy and the legitimacy of the Special Tribunal for Lebanon, 40 DEnver JournaL Of International Law And Policy 44-63 (2011).

Choi, Tae Hyun \& Kim, Sangkul, Nationalized International Criminal Law: Genocidal intent, command responsibility, and an overview of the South Korean implementing legislation of the ICC Statute, 19(3) Journal Of International Law And Practice 589-637 (2011).

Doherty, Heather Noel, Tipping the Scale: Is the Special Tribunal for Lebanon international enough to override state official immunity?, 43 Case Western Reserve Journal Of International Law 831876 (2011).

Farkasovska, Sylvia, The Mental Elements Of The Genocide Convention And The Khmer Rouge: The Mental Elements Of The Genocide Convention And The Khmer Rouge's Cambodia (VDM Verlag Dr. Müller 2011).

Goldstone, Richard J., South-East Asia And International Criminal Law: The 5Th Princess Maha Chakri Sirindhorn Lecture On International Humanitarian Law (Torkel Opsahl Academic EPublisher 2011).

Heugten, E. Van \& Verhoeven, I., Cambodia Tribunal: Selected Documents (International Courts Association 2011).

Hufnagel, Saskia \& Harfield, Clive \& Bronitt, Simon, Cross-Border Law Enforcement: Regional Law Enforcement Cooperation - European, Australian And Asia-Pacific Perspectives (Routledge 2011).

*Kanehara, Atsuko, Japanese Legal Regime Combating Piracy: The Act on Punishment of and Measures Against Acts of Piracy, 53 Japanese Yearbook Of International LaW 469 (2010).

Kim, Young Sok, The Korean Implementing Legislation on the ICC Statute, 10(1) Chinese Journal Of International Law 161-170 (2011).

Li, Peter, Japanese Militarism And Its War Crimes In Asia Pacific REGION (Global Future Institute 2011).

Liss, Carolin, Oceans Of Crime: Maritime Piracy And Transnational Security In Southeast Asia And Bangladesh (International Institute for Asian Studies (IIAS) 2011). 
Malekian, Farhad, Principles Of Islamic International Criminal Law: A Comparative Search (Brill 2011).

Marsh, Luke \& Ramsden, Michael, Joint Criminal Enterprise: Cambodia's reply to "Tadić”, 11 International CRiminal LAW Review 137-154 (2011).

McKinnon, Alexander, Maritime Piracy: A Hong Kong perspective, 41(3) Hong Kong Law Journal 635-658 (2011).

Okubo, Shiro \& Shelley, Louise, Human Security, Transnational Crime And Human Trafficking: Asian And Western PerspecTIVES (Routledge 2011).

Saul, Ben, Legislating from a Radical Hague - The United Nations Special Tribunal for Lebanon Invents an International Crime of Transnational Terrorism, 24 Leiden Journal Of International Law 677-700 (2011).

Shahabuddeen, Mohamed, Teething Phase of the ECCC, 10(3) Chinese Journal Of International LAW 469-502 (2011).

Tanaka, Yuki \& Mccormack, Tim \& Simpson, Gerry, Beyond Victor's Justice? The Tokyo War Crimes Trial Revisited (Brill 2011).

Tofan, C. \& Van Der Wolf, W., The Extraordinary Chambers In The Courts Of Cambodia: Case I Volume Iir Kaing Guek Eav (International Courts Association 2011).

Tsai, Lan Shiow, Singapore's Hostage Taking Act and the Accession to the International Convention against the Taking of Hostages, 4 JourNAL Of East Asia \& International Law 523-526 (2011).

Tsuruta, Jun, The Japanese Act on the Punishment of and Measures against Piracy, 1(2) Aegean Review Of The Law Of The Sea And MariTIME LAW 237-245 (2011).

Tsuruta, Jun, Agreement between Japan and the European Union on Mutual Legal Assistance in Criminal Matters, 4 Journal Of East Asia \& INTERNATIONAL LAW 235-37 (2011).

Zhu, Wenqi \& Zhang, Binxin, Expectation of Prosecuting the Crimes of Genocide in China, in Confronting Genocide 173-191 (R. Provost and P. Akhavan eds. 2011). 


\section{INTERNATIONAL DISPUTE SETTLEMENT}

Ali, Shahla F., Resolving Disputes In The Asia-Pacific Region: International Arbitration And Mediation In East Asia And The West (Routledge 2011).

Amer, Ramses \& Zou, Keyuan, Conflict Management And Dispute Settlement In East Asia (Ashgate 2011).

Greenberg, Simon, \& Kee, Christopher, \& Weeramantry, J. Romesh, International Commercial Arbitration: An Asia-Pacific Perspective (Cambridge University Press 2011).

Koh, Tommy, International Law and the Peaceful Resolution of Disputes: Asian perspectives, contributions and challenges, 1 AsIAn JOURNAL OF INTERNATIONAL LAW 57-60 (2011).

Lai, Amy, Taking the Hong Kong Tour Bus Hostage Tragedy in Manila to the ICJ? Developing a Framework for Choosing International Dispute Settlement Mechanisms, 45 The International Lawyer 673-694 (2011).

Lee, Ilhyung, Introducing International Commercial Arbitration and its Lawlessness, by Way of the Dissenting Opinion, 4 Contemporary Asia Arbitration Journal 19-36 (2011).

Maniruzzaman, A.F.M., Resolving International Business and Energy Disputes in Asia - Traditions and Trends, in Liber Amicorum EN L'honneur De Serge Lazareff (D. Laurent ed., Pedone 2011).

Moser, Michael \& Choong, John, Asia Arbitration Handbook (Oxford University Press 2011).

Shahbazinia, Morteza \& Tafreshi, Mohammad Issaei, Nationality of Parties and Arbitrator(s) in International Commercial Arbitration under Iranian Law, 14 International Arbitration Law Review 29-34 (2011).

Smith, Gordon \& Cook, Andrew, International Commercial Arbitration in Asia-Pacific: A comparison of the Australian and Singapore systems, 77 Arbitration 108-115 (2011).

Wang, Shuliang, Introduction to International Trade Dispute Settlement in China, in Globalization And Local Adaptation In Inter- 
national Trade Law (Pitman B. Potter and Ljiljana Biukovic eds., UBC Press 2011).

\section{DIPLOMATIC RELATIONS}

Iokibe, Makoto \& Eldridge, Rober, The Diplomatic History Of PostWAR JAPAN (Routledge 2011).

Kim, Kang-Nyeong, Korean Politics And Diplomacy In The Global Society (Shinji Press 2011).

*Ueki, Toshiya, Japan's Diplomatic Reactions toward the Kosovo's Declaration of Independence, 53 Ja PANESE Yearbook Of InTERnational LAW 457 (2010).

\section{HUMAN RIGHTS AND STATE PRACTICE}

Ahmad, Nehaluddin, Acid Attacks on Women: An appraisal of the Indian legal response, 12 Asia-Pacific Journal On Human Rights \& LAW 55-72 (2011).

Bariklou, Ali Reda, The Wife's Right of Divorce on the Basis of the Delegation Condition Under Islamic and Iranian Law, 25 (2) INTERNATIONAL Journal Of Law Policy Family 184-198 (2011).

Ceelen, Adinda, Myanmar's Unaccompanied Child Asylum Seekers In Thailand: Protection From Refoulement Under InternaTIONAL LAW (Utrecht University 2011).

Chang, Wen-Chen, The Convergence of Constitutions and International Human Rights: Taiwan and South Korea in comparison, 36 NorTH Carolina Journal Of International LaW And Commercial Regulation 593-624 (2011).

Davis, Thomas W.D. \& Galligan, Brian, Human Rights In Asia (Edward Elgar Publishing 2011).

Ghosh, Biswajit, Child Marriage, Society and the Law: A study in a rural context in West Bengal, India, 25 (2) International Journal OF Law Policy Family 199-219 (2011).

Shah, Dian Abdul Hamed \& Sani, Mohd Azizuddin Mohd, Freedom of Religion in Malaysia: A tangled web of legal, political, and social issues, 36 North Carolina Journal Of International Law And Commercial Regulation 647-688 (2011). 
Human Rights Documents, Outcome Document of the Second SubRegional Workshop on a Human Rights Mechanism in South Asia, 12 Asia-Pacific Journal On Human Rights \& Law 79-83 (2011).

Human Rights Documents, Kuala Lumpur Guidelines for a Human Rights Approach to Economic Policy in Agriculture, 12 Asia-PACIFIC Jou RNAL ON Human Rights \& LAW 81-98 (2011).

Jetschke, Anja, Human Rights And State Security: Indonesia And The Philippines (University of Pennsylvania Press 2011).

Kempadoo, Kamala \& Sanghera, Jyoti \& Pattanaik, Bandana, Trafficking And Prostitution Reconsidered, Second Edition: New Perspectives On Migration, Sex Work, And Human Rights (Paradigm Publishers 2011).

Klein, Richard, An Analysis of China's Human Rights Policies in Tibet: China's compliance with the mandates of international law regarding civil and political rights, 18 ILSA Journal Of INTERNATIONAL AND Comparative Law 115-165 (2011).

Lau, Holning \& Loh, Derek, Misapplication of ECHR Jurisprudence in W v Registrar of Marriages, 41(1) Hong Kong LaW Journal 75-88 (2011).

Lee, Gong Eunna, Contestations over Rights: From establishment to implementation of the National Basic Livelihood Security System in South Korea, 14 International Journal Of Human Rights 880-895 (2011).

Levenson, C., Tibet: A neo-colonial genocide, in Forgot ten Genocides: Oblivion, Denial And Memory 91-105 (R. Lemarchand ed., University of Pennsylvania Press 2011).

Limsira, Patthara, United Nations Rules for the Treatment of Women Prisoners and Non-Custodial Measures for Women Offenders (Bangkok Rules), 4 Journal Of East Asia \& International Law 241-243 (2011).

Lu, Haina, The Right To Work In China: Chinese Labor Legislation In The Light Of The International Covenant On Economic, Social And Cultural Rights (Intersentia 2011).

Matsui, Shigenori, Justice for the Accused or Justice for Victims: The protection of victims' rights in Japan, 13 Asia-Pacific Law \& Policy JOURNAL 54-95 (2011). 
Mohamad, Maznah, Malaysian Sharia Reforms in Flux: The changeable national character of islamic marriage, 25(1) INTERNATIONAL Journal Of Law Policy Family 46-70 (2011).

Moussa, Jasmine, Competing Fundamentalisms And Egyptian Women's Family Rights: International LaW And The Reform Of Sharia-Derived Legislation (Brill 2011).

Nasu, Hitoshi \& Saul, Ben, Human Rights In The Asia-Pacific Region: TowARDS Institution BuILDING (Routledge 2011).

Nathan, Andrew J., China and International Human Rights: Tiananmen's paradoxical impact, in The Impact Of China's 1989 Tiananmen Massacre (Jean-Philippe Béja ed., Routledge 2011).

Ol, Narith, Beer Promotion Girls - The Party Stops Here, How the legal \& cultural systems in Cambodia and the beer industry have allowed the exploitation of women, 29 WISCONSIN INTERNATIONAL LAW JOURNAL 202-231 (2011).

Phan, Hao Duy, A Selective Approach To Establishing A Human Rights Mechanism In South East Asia (UMI Dissertation Publishing 2011).

Putorti, Matthew F., The International Legal Right to Individual Compensation in Nepal and the Transitional Justice Context, 34 FordH AM INTERNATIONAL LAW JOURNAL 1131-1188 (2011).

Hofmann, Rainer \& Caruso, Ugo, Minority Rights In South Asia (Peter Lang 2011).

Ramamurthy, Subramanian, Towards a Human Rights Compatible Nuclear Liability Regime: Some human rights reflections from India, 15 INternational Journal Of Human Rights 1234-1248 (2011).

Razzaque, Jona, Linking Human Rights, Development and Environment: Experiences from litigation in South Asia, in Human Rights And The Environment (Dinah L. Shelton ed., Carolina Academic Press 2011).

Renshaw, Catherine \& Byrnes, Andrew \& Durbach, Andrea, Testing the Mettle of National Human Rights Institutions: A case study of the Human Rights Commission of Malaysia, 1 Asian Journal Of InTERNATIONAL LAW 165-198 (2011). 
Rhona, K. M., Equality of Nations Large and Small: Testing the theory of the universal periodic review in the Asia-Pacific, 12 Asia-Pacific Journal On Human Rights \& LAw 36-54 (2011).

Sagar, Rajiv, Violence, Law And Women's Rights In South Asia (Cyber Tech Publications 2011).

Saul, Ben \& Mowbray, Jacqueline \& Baghoomians, Irene, The Last Frontier of Human Rights Protection: Interrogating resistance to regional cooperation in the Asia-Pacific, 18 Australian International LAW Journal 23-52 (2011).

Serajuddin, Alamgir Muhammad, Muslim Family law, Secular Courts And Muslim Women Of South Asia: A Study In Judicial Activism (Oxford University Press 2011).

Sharom, Azmi \& Petcharamesree, Sriprapha \& Sumarlan, Yanuar, Breaking The Silence Southeast Asian Human Rights Studies NETWORK (SEAHRN 2011).

Smith, Rhona K.M., More of the Same or Something Different? Preliminary Observations on the Contribution of Universal Periodic Review with Reference to the Chinese Experience, 10(3) Chinese Journal Of INTERNATIONAL LAW 565-586 (2011).

Steiner, Kerstin, Religion and Politics in Singapore: Matters of national identity and security?: A case study of the Muslim minority in a secular state, 58 OsAKA UNIVERSity LAw REview 107-133 (2011).

Subedi, Surya P., The UN Human Rights Mandate in Cambodia: The challenge of a country in transition and the experience of the special rapporteur for the country, 15 The International Journal Of Human Rights 249-294 (2011).

Tan, Hsien-Li, The Asean Intergovernmental Commission On Human Rights: Institutionalising Human Rights In Southeast Asia (Cambridge University Press 2011).

Tursan, Gulazat, Integrating Minorities through Legislation: A Chinese point of law, 12 Asia-Pacific Journal On Human Rights \& LaW 27-55 (2011).

Waites, Matthew, Human Rights, Sexual Orientation and the Generation of Childhoods: Analysing the partial decriminalisation of 'unnatural 
offences' in India, 14 International Journal Of Human Rights 971-993 (2011).

Webster, Timothy, Insular Minorities: International law's challenge to Japan's ethnic homogeneity, 36 North Carolina Journal Of International Law And Commercial Regulation 557-592 (2011).

Weir, Lane, Under Review: Burma's failure to comply with the Convention on the Rights of the Child, 38 LEgAL Journal ON Burma 18-28 (2011).

Wolman, Andrew, National Human Rights Institutions and the Courts in Asia-Pacific Region, 19 Asia Pacific Law Review 237-252 (2011).

Wook, Izawati Bt, The Role of the International Human Rights Norms in Malaysian Courts, 5 The Malayan Law Journal cxlviii-clxiv (2011).

Yap, Po Jen \& Lau, Holning, Public Interest Litigation In Asia (Routledge 2011).

Yong, Xia, The Philosophy Of Civil Rights In The Context Of China (Brill 2011).

Mansoor, Farkhanda Zia, Working Towards The Eradication Of Child Labour? An Analysis Of The L Framework With CaseStudies Of Pakistan, India, Indonesia, China, Uk And Usa (CMP Publishing 2011).

\section{COLONIALISM, DECOLONIZATION, AND SELF DETERMINATION}

Hong, Yun-Gi, Dichotomously Stiffened Dialectics in the Entangled Modernity of the Colonized and the Colonizers: A critical comment on Professor Singh's article, “Colonised's Madness, Colonisers' Modernity and International Law: Mythological Materialism in the East-West teleos", 4 Journal Of East Asia \& International LaW 105-114 (2011).

Mutaqin, Zezen Zaenal, Indonesian Customary Law and European Colonialism: A comparative analysis on Adat Law, 4 Journal Of East Asia \& International LAW 351-376 (2011). 


\section{INTERNATIONAL ECONOMIC AND FINANCIAL LAW}

Ahn, Dukgeun \& Lee, Jieun, Countervailing Duty against China: Opening a Pandora's box in the WTO System?, 14 (2) Journal Of InTERnTAIONAL ECONOMIC LAW 329-368 (2011).

Bath, Vivienne \& Nottage, Luke, Foreign Investment And Dispute Resolution Law And Practice In Asia (Routledge 2011).

Blanco, Elena \& Dung, Tran Anh \& Turksen, Umut, Evolving to Perfection?: Enforcement of international arbitral awards in Vietnam, 11 JOURNAL Of World Investment And Trade 965-1017 (2011).

Buckley, Ross P. \& Hu, Richard Weixing \& Arner, Douglas W., East Asian Economic Integration: Law, Trade And Finance (Edward Elgar Publishing 2011).

Burch, Micah \& Nottage, Luke, Novel Treaty-Based Approaches to Resolving International Investment and Tax Disputes in the Asia-Pacific Region, 18 Australian International Law Journal 127-140 (2011).

Chang, Seung Wha \& Choi, Won-Mog, Trade Law And Regulation In Korea (Edward Elgar Publishing 2011).

Chen, Zhichao, Cross-Strait Economic Cooperation Framework Agreement: Deliberation on economic, political and legal aspects, 4 JourNAl Of EAst Asia \& International Law 153-72 (2011).

Delimatsis, Panagiotis, Protecting Public Morals in a Digital Age: Revisiting the WTO Rulings on US - gambling and China - publications and audiovisual products, 14(2) Journal Of InTERNATIONAL ECONOMIC LAw 257-293 (2011).

Ewing-Chow, Michael \& Fischer, Geraldine R., ASEAN IIAs: Conserving regulatory sovereignty while promoting the rule of law?, 8(5) TRANSnational Dispute Management 1-12 (2011).

Gao, Henry, Elephant in the Room: Challenges of integrating China into the WTO system, 6 Asian Journal Of Wto \& International Health Law \& Policy 137-68 (2011).

Gao, Henry, Google's China Problem: A case atudy on trade, technology and human rights under the GATS, 6 Asian Journal of WTO \& International Health LaW \& Policy 349-388 (2011). 
Hasan, Zulkifli, A Survey On "Shari'ah" Governance Practices In Malaysia, Gcc Countries And The UK: Critical Appraisal (Emerald 2011).

He, Juan, Developing Countries' Pursuit of an Intellectual Property Law Balance under the WTO TRIPS Agreement, 10(4) CHINESE JournaL Of INTERNATIONAL LAW 827-863 (2011).

Hsieh, Pasha L., The China-Taiwan ECFA, Geopolitical Dimensions and WTO Law, 14(1) Journal Of International Economic Law 121156 (2011).

Islam, Rizwanul, Economic Integration In South Asia: Charting A Legal Roadmap (Martinus Nijhoff Publishers 2011).

Jernudd, Sigrid Ursula, China, State Secrets and the Case of Xue Feng: The implication for international trade: Comment, 12 CHICAgo JournaL Of INTERNATIONAL LAW 309-339 (2011).

Kawai, Masahiro \& Wignaraja, Ganeshan, Asia's Free Trade Agreements: How Is Business Responding? (Edward Elgar Publishing 2011).

Lai, Yen-Hsueh, Interpreting the ECFA: A new common market for Taiwan and Mainland China, 4 Journal Of East Asia \& International LAW 173-192 (2011).

Lee, Yong-Shik \& Lee, Jaemin \& Sohn, Kyung Han, United States-Korea Free Trade Agreement - Path to common economic prosperity or false promise?, 6 University Of Pennsylvania East Asia Law REVIEW 111-162 (2011).

Li, Hong, Depoliticization and Regulation of Sovereign Wealth Funds: A Chinese perspective, 1 Asian Journal Of International LaW 403-422 (2011).

Lim, C.L., East Asia's Engagement with Cosmopolitan Ideals under its Trade Treaty Dispute Provisions, 56 Mcgill Law Journal 821-855 (2011).

Kelsey, Jane, The Conundrum of Shifting Orthodoxies: FTAs And Korea's currency controls, 14(4) Journal Of International Economic LAW 848-868 (2011). 
Ko, Bomin, Trade in Goods Agreement of the FTA between Korea and the ASEAN: The four years and beyond, 4 Journal Of EAst Asia \& INTERNATIONAL LAW 519-522 (2011).

Lee, Yong-Shik Et Al., Law And Development Perspective On InTernational Trade Law (Cambridge University Press 2011).

Mercurio, Bryan, Trade Liberalisation in Asia: Why intra-Asian Free Trade Agreements are not utilised by the business community, 6 Asian Journal Of Wto \& International Health Law \& PolicY 109-36 (2011).

Mölders, Florian \& Volz, Ulrich, Trade Creation and the Status of FTAs: Empirical evidence from East Asia, 147 Review Of World ECONOMICs 429-456 (2011).

Moon, Gillian, Fair in Form, But Discriminatory in Operation-WTO Law's Discriminatory Effects on Human Rights in Developing Countries, 14 (3) Journal Of International Economic Law 553-592 (2011).

Pang, Eul-Soo, The U. S. - Singapore Free Trade Agreement: An American Perspective On Power, Trade And Security In The Asia PaCific (Institute of Southeast Asian Studies 2011).

Park, Donghyun \& Estrada, Gemma Esther, Developing Asia's Sovereign Wealth Funds: The Santiago Principles and the case for self-regulation, 1 Asian Journal Of International Law 383-402 (2011).

Potter, Pitman B. \& Biukovic, Ljiljana, Globalization And Local Adaptation In International Trade Law (UBC Press 2011).

Priti, N. Emani, Globalization versus Normative Policy: A case study on the failure of the Barbie doll in the Indian market, 13 Asian-PACIFIC LAW \& POLICY JOURNAL 96-128 (2011).

Qin, Julia Ya, Pushing the Limits of Global Governance: Trading rights, censorship and WTO jurisprudence-a commentary on the ChinaPublications case, 10(2) Chinese Journal Of International LaW 271-322 (2011).

Ran, Anh L.T., Patent Law and Public Health Under the TRIPS Agreement Standards: How does Vietnam benefit from the WTO membership?, 14 Journal Of World Intellectual Property 334-352 (2011). 
Saggi, Kamal \& Trachtman, Joel P., Incomplete Harmonization Contracts in International Economic Law: Report of the Panel, China - Measures Affecting the Protection and Enforcement of Intellectual Property Rights, 10 World Trade Review 63-86 (2011).

Shin, Hi-Ta \& Kim, Julie A., Balancing the Domestic Regulatory Need to Control the Inflow of Foreign Direct Investment against International Treaty Commitments: A policy-oriented study of the Korean Foreign Investment Promotion Act and the Korea-US FTA, 19 Asi A PACIFIC LAW REVIEW 177-94 (2011).

*Sugihara, Daisaku, Investment Chapter of the Japanese-Switzerland Free Trade Economic Partnership Agreement (JSFTEPA): A comparative study of the "Japan Model" in the context of the evolution of international investment agreements, 53 Japanese Yearbook Of INTERNATIONAL LAW 122 (2010).

Supancana, I.B.R., Legal Issues regarding Foreign Investment and the Implementation of the Japan-Indonesia Economic Partnership Agreement, 4 Journal Of East Asia \& International Law 131-52 (2011).

Tsai, Chang-hsien, Exit Voice and International Jurisdictional Competition: A case study of the evolution of Taiwan's regulatory regime for outward investment in mainland China, 1997-2008, 39 Syracuse Journal Of International Law And Commerce 303-355 (2011).

Wang, Guiguo, Radiating Impact Of WTO On Its Members' Legal System: The Chinese Perspective (Brill 2011).

Li, Wanqiang, Chinese Foreign Investment Laws: A review from the perspective of policy-oriented jurisprudence, 19 Asia PaCific LAW Review 35-52 (2011).

Wahab, Sazali Abdul, Asean Free Trade Area (Afta): The Impact On The Automotive, Palm Oil And Banking Industries In Malaysia (LAP Lambart Academic Publishing 2011).

Yu, Yanning, China's Adopting Emergency Safeguard Measures for Services: A political economy analysis, 6 Asian Journal Of Wto \& International Health Law \& Policy 429-454 (2011).

Zhang, Liang, Unprecedented RTA Practices between the Customs Territories of China, 4 Journal Of East Asia \& International Law 81-104 (2011). 


\section{DEVELOPMENT}

Anand, R.P., International Law And The Developing Countries: Confrontation Or Cooperation? (Hope India 2011).

Baldacchino, Godfrey \& Niles, Daniel, Island Futures: Conservation And Development Across The Asia-Pacific Region (Springer 2011).

Byrnes, Andrew, The Asian Development Bank and the Role of Human Rights in the Pursuit of Just and Sustainable Development in the Asia-Pacific Region: An advocacy role for Australia, 18 Australian INTERNATIONAL LAW JOURNAL 1-21 (2011).

Cedar, Oded, Failure of Conscience: How Pakistan's devastating floods compare to America's experience during Katrina, 11(1) Sustaina BLE Development Law \& Policy 46 (2011).

Cheema, G. Shabbir \& Mcnally, Christopher A. \& Popovski, Vesselin, Cross-Border Governance In Asia: Regional Issues And Mechanisms (United Nations University Press 2011).

Iqbal, Khurshid, Right to Development at the National Level and Pakistan's Judiciary, 12 Asia-Pacific Journal On Human Rights \& Law 1-26 (2011).

Malhotra, Shriya, Population Health through Inclusive Urban Planning: Healthier communities and sustainable urban development in Indian cities, 11(1) Sustainable Development Law \& Policy 51-57 (2011).

Niaz, Ilhan, Provincial Administration in Pakistan and the Crisis of Order and Development, 34 (2) South Asia: Journal Of South Asian STUdiEs 232-254 (2011).

Nixon, Rod, Justice And Governance In East Timor: Indigenous Approaches And The 'New Subsistence State' (Routledge 2011).

Pepper, Emmett, Time-of-Use Pricing Could Help China Manage Demand, 11(1) Sustainable Development Law \& Policy 18 (2011).

Phua, Stephen, Taxation and Non-Taxation Measures for Sustainable Development in Singapore, in The Law And Practice Of Singapore InCOME TAX 1045-1073 (LexisNexis 2011). 
Qerimi, Qerim, Development as a Universe of Human Aspirations: A New Haven School perspective, 19 Asia Pacific Law Review 113-133 (2011).

\section{INFORMATION AND COMMUNICATION}

Liu, Yangyue, Crafting a Democratic Enclave on the Cyberspace: Case studies of Malaysia, Indonesia, and Singapore, 30 Journal Of Current Southeast Asian Affairs 33-55 (2011).

Tsai, Katherine, How to Create International Law: The Case of Internet Freedom in China, 21 Duke Journal Of Comparative And InTERNATIONAL LAW 401-430 (2011).

Vaagan, Robert W., Media Systems, Access to Information and Human Rights in China and Vietnam, 29 Nordic Journal Of Human Rights 302-328 (2011).

\section{INTERNATIONAL/REGIONAL ORGANIZATIONS}

Tan, Hsien-Li, Non-state Actors in Southeast Asia: How does civil society contribute towards norm-building in a state-centric environment?, in Participants In The International Legal System: Multiple Perspectives On Non-State Actors In International Law 109-125 (Jean d'Aspremont ed., Routledge 2011).

Weber, Katja, Lessons from the ASEAN Regional Forum: Transcending the image of paper tiger, in The Security Governance Of Regional Organizations (Emil J. Kirchner and Roberto Domínguez eds., Rutledge 2011).

Abanes, Menandro, ASean Way Of Peacebuilding Through Performing Arts, Community Building, And Humanitarian OpERATIONS (GRIN Verlag 2011).

Aekaputra, Prasit, Report on the ASEAN Economic Cooperation and Integration, 2 European Yearbook Of International Economic LAW 375-386 (2011).

Desierto, Diane A., ASEAN's Constitutionalization of International Law: Challenges to evolution under the new ASEAN Charter, 49 CoLumbia Journal Of Transnational LaW 268-320 (2011). 
Dosch, Jorn, Reconciling Trade and Environmental Protection in ASEANChina Relations: More than political window dressing?, 30 JournaL Of Current Southeast Asian Affairs 7-29 (2011).

Emmers, Ralf, ASEAN And The Institutionalization Of East Asia (Routledge 2011).

Hamanaka, Shintaro, Japan's Foreign Direct Investment in Services in ASEAN: The implications of services and investment agreements, 12 Journal Of World Investment And Trade 351-376 (2011).

Lee, Seryon, Agreement on the Establishment of the Trilateral Cooperation Secretariat among the Governments of Japan, the People's Republic of China and the Republic of Korea, 4 Journal Of East Asia \& INTERNATIONAL LAW 238-240 (2011).

Lee, Yoong, Asean Matters!: Reflecting On The Association Of Southeast Asian Nations (World Scientific Publishing Company 2011).

Leu, Guanyi, ASEAN's Preferential Trade Agreements (PTA) Strategy, 30 Journal Of Current Southeast Asian Affairs 31-64 (2011).

Li, Minguiang \& Kwa, Chong Guan, China-Asean Sub-Regional Cooperation: Progress, Problems, And Prospect (World Scientific Publishing Company 2011).

Munroe, James, The Relationship between the Origins and Regime Design of the ASEAN Intergovernmental Commission on Human Rights (AICHR), 15 International Journal Of Human Rights 11851214 (2011).

Xiao, Jun, The ASEAN-China Investment Agreement: A regionalization of China's BITs, 6 Frontiers Of Law In China 241-258 (2011).

Zou, Keyuan, China-ASEAN Relations And International LaW (Chandos Asian Studies 2011).

\section{PRIVATE INTERNATIONAL LAW}

Mahasneh, Nisreen, The Ratification of the United Nations Convention on Contracts for the International Sale of Goods by Jordan: The legal perspective and impact, 16 Uniform LaW Review 843-865 (2011). 
Aldohni, Abdul Karim, The Legal And Regulatory Aspects Of Islamic Banking: A Comparative Look At The United Kingdom And Malaysia (Routledge 2011).

Antons, Christoph, The Enforcement Of Intellectual Property Rights: Comparative Perspectives From The Asia-Pacific ReGION (Kluwer Law International 2011).

Chaudhry, Shohit \& Mahajan, Kartikey, The Case for an Effective Extraterritorial Jurisdiction of the Competition Commission of India in Light of International Practices, 32 European Competition Law REVIEW 314-320 (2011).

${ }^{\star}$ Chen, Weizuo, Chinese Private International Law Statute of 28 October 2010, 12 Yearbook Of Private International Law 27-41 (2010).

*Ebrahimi, Seyed N., An Overview of the Private International Law of Iran: Theory and practice (Part One), 12 YeArbook Of Private INTERNATIONAL LAW 503-530 (2010).

Ganesh, Selvi, Indian Shipping and International Maritime Law, 51 IndIAN JOURNAL OF INTERNATIONAL LAW 378-407 (2011).

Hunter, Howard, Singapore Contract Law in an Interdependent World of Commerce: The example of the Convention on the International Sale of Goods, in SAL Conference 2011: Developments In Singa pore Law Between 2006 And 2010: Trends And Perspectives (Yeo Tiong Min, Hans Tjio, Tang Hang Wu eds., Singapore Academy Publishing 2011).

Huo, Zhengxin, Highlights of China's New Private International Law Act: From the perspective of comparative law, 45 RevUe JURIDIQUE THÉmis 637-684 (2011).

Jambholkar, Lakshmi, India and the 1980 Hague Convention on Civil Aspects of International Child Abduction, 51 Indian Journal OF INTERNATIONAL LAW 85-96 (2011).

*Kojima, Ryu, Contemporary Problems in Japanese Intellectual Property Law: Copyright limitations and exceptions, indirect copyright infringement, and selected issues related to private international law, 53 Japanese Yearbook Of International Law 358-376 (2010). 
Kumar, Ranjeet \& Tripathi, R. C. \& Tiwari, M. D., A Case Study of Impact of Patenting in the Current Developing Economies in Asia, 88 SCIENTOMETRICS 575-587 (2011).

Lapiashvili, Natia, Modern Law Of Contracts And Sales In Eastern Europe And Central Asia (Eleven International Publishing 2011).

Mcewin, R. Ian, Intellectual Property, Competition law And Economics In Asia (Hart Publishing 2011).

Nishitani, Yuko, The Hague Convention on International Child Abduction and Japan's Move Toward Ratification, 16 Zeitschrift FÜr JAPANISCHES RECHT 261-264 (2011).

*Sakai, Hajime, Enforcing the Obligation to Return a Child in Japan: With insight into the recognition and enforcement of foreign judgments in cross-border child abduction cases, 53 Japanese Yearbook Of INTERNATIONAL LAW 438 (2010).

*Sono, Hiroo, Japan's Accession to and Implementation of the United Nations Convention on Contracts for the International Sale of Goods (CISG), 53 Japanese Yearbook Of International Law 410-437 (2010).

Suk, Kwang Hyun, Some Observations on the Chinese Private International Law Act: Korean Law perspective, 18 ZeItschrift Für CHINEsisches ReCHT 105-115(2011).

Wei, George, Of Copying, Reproduction, Substantiality and Copyright: A view from Singapore, 33 European Intellectual Property Review 384-394 (2011).

19. NUCLEAR

Gupta, Mohit Kumar, India's 2010 Civil Liability for Nuclear Damage Act: An analysis of domestic and international legal issues, 51 Indian Journal Of International LaW 100-109 (2011).

\section{CULTURAL PROPERTY}

Cox, Douglas, "Inalienable" Archives: Korean royal archives as French property under international law, 18 International Journal Of Cultural Property 409-423 (2011). 